\title{
PERAN PENDIDIKAN AGAMA KRISTEN DALAM MEMERANGI BERITA HOAKS DI MEDIA SOSIAL
}

\author{
Talizaro Tafonao \\ Sekolah Tinggi Teologi KADESI Yogyakarta \\ Korespondensi: talizarotafonao@gmail.com \\ Prasetyo Yuliyanto \\ Mahasiswa Pascasarjana Sekolah Tinggi Teologi KADESI Yogyakarta \\ yuliyantoprasetyo31@gmail.com
}

\begin{abstract}
In this study, the author studies the role of Christian religious education in combating hoax on social media. This study begins with the author's empirical observation where these days hoax on social media becomes the main news that is endlessly discussed in public. As a result of many hoaxes on social media, there are many divisions between the people as expressed in this empirical study. If it is carefully observed that the main problem is not in the development of science and technology globally, but the problem is there are every person who uses the technology irresponsibly because humans are too spoiled with various facilities of technological sophistication so that there is no control when someone is free to express opinions in social media. Ironically this freedom is exploited to explore personal and group interests, without seeing the consequences of this dishonourable behaviour. By looking at these various facts, this study presents an effort to provide understanding and education to the public to participate in combating hoax on social media. The purpose of this study is to invite all Christians to contribute and care for the social problems that are troubling society today. Therefore it is time for the role of Christian Religion education to be applied through lifestyles by communicating honestly and get used to using ethics when surfing on social media.
\end{abstract}

Keywords: christian education, religion, prevent, hoaks, social media

\begin{abstract}
Abstrak
Tulisan ini merupakan kajian terhadap peran pendidikan agama kristen dalam memerangi berita hoaks di media sosial. Kajian ini berangkat dari pengamatan penulis secara empiris dimana hari-hari ini berita hoaks di media sosial menjadi berita utama yang tidak habisnya dibicarakan di publik. Akibat dari mewabahnya berita hoaks di media sosial maka tidak sedikit terjadinya perpecahan diantara masyarakat sebagaimana yang diungkapkan dalam tulisan ini seacara empiris. Jika diperhatikan dengan teliti bahwa unsur persolan sebenarnya bukan terletak pada perkembangan ilmu dan teknologi secara global, tetapi persoalannya adalah ada pada setiap oknum yang memanfaatkan teknologi tersebut karena manusia terlalu dimanjakan dengan berbagai fasilitas dari kecanggihan teknologi tersebut sehingga tidak ada kontrol ketika seseorang bebas mengeluarkan berpendapat di media sosial. Dengan melihat berbagai fonomena ini maka tulisan ini hadir sebagai upaya memberi pemahaman dan edukasi kepada masyarakatuntuk ikut berpatisipasi dalam memerangi berita hoaks di media sosial. Tujuan kajian ini mengajak seluruh umat Tuhan untuk berkontribusi dan peduli terhadap persolan-persoalan sosial yang sedang meresahkan masyarakat saat ini.
\end{abstract}

Kata Kunci: pendidikan kristen, agama, menangkal, hoaks, media sosial 


\section{Pendahuluan}

Tulisan ini mengkaji begaimana upaya dalam memerangi berbagai berita hoaks di media sosial. Penulis mengamatinya bahwa lewat sektor Pendidikan khususnya Pendidikan Agama Kristen menjadi salah satu paling efektif dalam memerangi berita hoaks tersebut. Namun, dengan melihat kenyataannya masih ditemukan persoalan-persoalan yang belum tuntas seperti yang akan ditampilkan dalam tulisan ini. Harus diakui bahwa kemajuan teknologi merupakan sesuatu yang tidak bisa dihindari oleh setiap orang, karena kemajuan teknologi telah berjalan sesuai dengan perkembangan ilmu dan terus berkembang termasuk teknologi informasi dan komunikasi. Hal ini nampak dalam segala aktivitas baik dunia usaha, pendidikan, medis dan seni dituntut untuk memanfaatkan kemajuan teknologi informasi sebagai sarana untuk berkomunikasi, salah satunya adalah internet.

Internet sebuah jaringan besar yang dapat menghubungkan ke komputer, baik organisasi bisnis, pemerintah, sekolah, dan dapat menjangkau jutaan orang di seluruh dunia, ${ }^{1}$ demi memperlancar mobilitasi pelayanan dan komunikasi. Sebab, perkembangan teknologi, informasi dan komunikasi telah mengalami perubahan yang dinamis, ${ }^{2}$ dan masyarakat harus memanfaatkannya sebagai sarana dalam mempermudah segala pekerjaan yang ada, karena kehadiran teknologi memberi kemudahan dan inovasi-inovasi baru yang dapat digunakan oleh setiap manusia. ${ }^{3}$ Misalnya pada tanggal 16 Maret 2020 semua kampus yang ada di Indonesia diliburkan untuk menghindari penyebaran Covid-19 (Virus Corona) namun proses perkuliahan tetap dilaksanakan melalui online yakni video conference, live streaming, daring dan media lain seperti via e-mail, whatsapp dan lain sebagainya. Dengan adanya teknologi ini memberi manfaat khususnya dalam dunia pendidikan. Salah satu manfaat dari teknologi informasiini yakni memberi kemudahan dalam pengurusan segala administrasi akademik, dan proses belajar mengajar. ${ }^{4}$

Tidak hanya dunia pendidikan yang merasakan manfaat ini, namun masyarakat secara umum telah merasakan hal-hal baru yang disajikan oleh teknologi itu sendiri. Zaman dahulu penggunaan gawai hanya sebatas alat komunikasi jarak jauh. Kemudian berkembang sehingga mampu mengirim pesan teks dalam jarak jauh dengan waktu yang cepat. Selain itu, gawai tidak hanya sebatas alat komunikasi baik suara dan teks tetapi juga sebagai alat sumber informasi. Sebelum era digital ada, orang-orang mencari informasi melalui surat kabar atau buku tetapi sekaranghanya dengan gawai seseorang bisa mendapatkan berbagai informasi di seluruh dunia. Karena pada dasarnya gawai atau gadget ini diciptakan untuk keperluan komunikasi serta untuk mendapatkan informasi demi kepentingan pribadi sehingga peminatnya sangat tinggi dan bervariasi mulai dari remaja, pemuda sampai kepada orang tua. ${ }^{5}$

${ }^{1}$ Astrid Kurnia Sherlyanita and Nur Aini Rakhmawati, "Pengaruh Dan Pola Aktivitas Penggunaan Internet Serta Media Sosial Pada Siswa SMPN 52 Surabaya," Journal of Information Systems Engineering and Business Intelligence 2, no. 1 (2016): 17.

${ }^{2}$ Cecep Abdul Cholik, "Pemanfaatan Teknologi Informasi Dan Komunikasi Untuk Meningkatkan Pendidikan Di Indonesia," Syntax Literate : Jurnal Ilmiah Indonesia 2, no. 6 (2017): 21-31.

${ }^{3}$ Muhamad Ngafifi, "Kemajuan Teknologi Dan Pola Hidup Manusia Dalam Perspektif Sosial Budaya," Jurnal Pembangunan Pendidikan: Fondasi dan Aplikasi 2, no. 1 (2014): 33-47.

4Pasaribu Humisar Parsaorantua, Yuriewati Pasoreh, and Sintje A. Rondonuwu, "Implementasi Teknologi Informasi Dan Komunikasi (Studi Tentang Web E-Government Di Kominfo Kota Manado)," Acta Diurna VI, no. 3 (2017): 1-14.

${ }^{5}$ Nurmalasari and Devi Wulandari, "Pengaruh Penggunaan Gadget Terhadap Tingkat Prestasi Siswa SMPN Satu Atap Pakisjaya Karawang," JURNAL ILMU PENGETAHUAN DAN TEKNOLOGI KOMPUTER 3, no. 2 (2018): 111-118. 
Berdasarkan penjelasan di atas, penulis mengamati bahwa kehadiran teknologi saat ini seharusnya masyarakat dapat memanfaatkan dengan baik dan cerdas, karena tidak hanya cerdas dalam ilmu pengetahuan tetapi cerdas dalam menggunakan media sosial sebagai sarana untuk berkomunikasi dalam menunjang segala aktivitas yang dijalankan setiap hari. Senada dengan apa yang dijelaskan oleh Pasaribu bahwa dengan adanya teknologi informasi dan komunikasi maka seseorang lebih dinamis dalam mendapatkan tentang peristiwa dari jauh serta membantu segala urusan dalam menyampaikan informasi secara cepat. ${ }^{6}$ Dengan penjelasan ini seharusnya itu yang terjadi tetapi pada kenyataannya tidak seperti itu karena masih ada di antara masyarakat yang menggunakan teknologi informasi sebagai sarana untuk menyebarkan berita bohong atau hoaks di media sosial. Salah satu kasus yang terjadi di Asrama Papua di Surabaya pada bulan Agustus 2019 telah menyita perhatian masyarakat Indonesia. Menurut Kapolda Jatim Irjen Pol Luki Herman pada tanggal 4 Sepetember 2019 menjelaskan bahwa masalah ini berawal dari berita hoaks yang mengandung isu provokasi dan rasisme di media sosial sehingga berujung kepada kerusuhan di berbagai daerah. Selain kasus tersebut, pada tanggal 17 Maret 2020 Polri mengamankan sekitar 22 Pelaku Penyebar berita Hoaks tentang Covid-19 di Indonesia. Menurut penjelasan Kombes Pol Asep Adi Saputra kepada wartawan bahwa orang-orang yang diduga penyebar berita hoaks ini di media sosial masih dalam tahap proses penyedik karena kasusnya beragam dari berbagai daerah di Indonesia. ${ }^{7}$ Tetapi yang lebih mengejutkan lagi dengan hanya berselang dua hari Polri kembali mengumumkan 8 orang tersangka baru dugaan penyebaran berita bohong atau hoaks tentang Virus corona atau Covid-19 pada tanggal 19 Maret 2020, sehingga jumlah tersangka bertambah 30 orang.

Dengan melihat berbagai kasus di atas, menurut hemat penulis bahwa kecanggihan teknologi yang berbasis internet di era digital seharusnya menjadi media dalam memperoleh informasi serta sarana untuk berkomunikasi kepada orang lain tetapi sebaliknya yang terjadi saat ini masih banyak orang yang belum sadar tentang bahaya dalam memposting berita hoaks di media sosial seperti yang telah dijelaskan sebelumnya. Akibat dari ketidakhatihatian dalam berkomunikasi melalui media sosial akhirnya tidak sedikit masyarakat berurusan dengan hukum karena ulah sendiri sebab tindakannya telah menimbulkan keresahan dan kegaduhan di masyarkat. Karena pada dasarnya hoaks merupakan berita yang direkayasa oleh seseorang demi menutupi informasi yang sesungguhnya kepada publik. Dengan kata lain bahwa hoaks sebagai upaya untuk memutarbalikan kebenaran (fakta) dengan menggunakan media sosial sebagai sarana untuk meyakinkan orang lain seolah-olah kejadian tersebut benar-benar terjadi tetapi pada kenyataan tidak dapat diverifikasi kebenarannya. ${ }^{8}$

Oleh karena itu, sebaiknya masyarakat harus bijak dalam memanfaatkan media sosial dengan memastikan terlebih dahulu sumber informasi dan konten yang akan dibagikan kepada orang lain. ${ }^{9}$ Bagi penulis hal ini tidak cukup hanya memberi himbauan dan edukasi kepada masyarakat, namun yang terpenting adalah pemerintah beserta dengan penegak hukum harus kerja keras memerangi aksi-aksi tidak terpuji inidi media sosial karena melalui perilaku seperti ini dapat menimbulkan perpecahan di masyarakat. Sejauh ini pemerintah

6Parsaorantua, Pasoreh, and Rondonuwu, "Implementasi Teknologi Informasi Dan Komunikasi (Studi Tentang Web E-Government Di Kominfo Kota Manado)."

"Irfan Ma'ruf, "Polri Amankan 22 Pelaku Penyebar Hoaks Virus Korona Di Indonesia," INews.Id.

${ }^{8}$ Gumgum Gumilar, Justito Adiprasetio, and Nunik Maharani, "Literasi Media: Cerdas Menggunakan Media Sosial Dalam Menanggulangi Berita Palsu (Hoax) Oleh Siswa Sma," Pengabdian Kepada Masyarakat 1, no. 1 (2017): 35-40.

${ }^{9}$ Dedi Rianto Rahadi, "Perilaku Pengguna Dan Informasi Hoax Di Media Sosial," Jurnal Manajemen Dan Kewirausahaan 5, no. 1 (2017): 58-70. 
telah berupaya menggalakkan kampanye untuk mengurangi atau menghentikan penyebaran berita hoaks dengan cara menangkap para pelaku dan memblokir beberapa akun palsu di media sosial, dan bahkan tidak hanya itu pemerintah telah menerbitkan Undang-undang ITE untuk menjerat para pelaku penyebar berita hoaks di media sosial.

Selanjutnya berdasarkan kajian penelitian yang sudah dilakukan beberapa tahun belakangan ini memberi informasi bahwasalah satu sarana yang paling efektif dalam menyebarkan berita hoaks adalah melalui situs web, sebesar $34,90 \%$, aplikasi chatting seperti Whatsapp, Line Telegram sebesar 62,80\%, dan melalui media sosial yakni Facebook, Twitter, Instragram, dan Path mencapai $92,40 \% .{ }^{10} \mathrm{Hal}$ ini menunjukkan bahwa pengaruh media teknonologi di era digital sangat besar sebagai sarana dalam menciptakan suasana yang tidak menyenangkan atau kondusif di publik. Dengan angka persentase seperti ini tidak mudah bagi pemerintah dan penegak hukum dalam memerangi berbagai kasus hoaks, karena jenis hoaks sangat beragam seperti masalah kesehatan, makanan, politik, SARA (Suku, Agama, Ras, dan Antar Golongan), hingga bencana alam. Oleh sebab itu, semua elemen masyarakat dan lembaga pendidikan, agama, sosial diajak turut mengambil bagian dalam memerangi berbagai kasus tersebut di atas untuk mengurangi beban pemerintah sekaligus sebagai bukti warga Negara Indonesia yang baikdan cinta dengan Pancasila. Salah satu peran masyarakat dalam memerangi atau menangkal hoaks adalah masyarakat melakukan pengecekan terhadap informasi yang tersebar di publik dengan menggunakan sumber-sumber media yang terpercaya dan saling bekerja sama satu dengan yang lain dalam memverifikasi tentang hoaks yang sedang beredar sehingga tidak mudah terprovokasi. ${ }^{11}$ Dengan penjelasan dan pemaparan ini, maka disini pentingnya peran Pendidikan Agama Kristen. Bahwa orang Kristen seharusnya cerdas dan tidak boleh ikutanikutan dalam menyebarkan berita hoaks di media sosial. ${ }^{12}$ Sebab hal ini sangat bertentangan dengan apa yang dipesankan oleh Tuhan Yesus dalam Injil Matius 15: 14-16; dan Roma. 12:2.

Berdasarkan permasalahan latar belakang di atas dengan kondisi yang terjadi sekarang ini, maka penulis mengkaji Peran Pendidikan Agama Kristen dalam Memerangi Berita Hoaks di Media Sosial. Tujuan dari karya tulis ini adalah untuk memberi pemahaman dan edukasi kepada masyarakat khususnya umat Kristen agar memanfaatkan media sosial sebagai tempat berkomunikasi dalam menyampaikan informasi yang benar kepada publik tanpa merugikan diri sendiri dan orang lain serta tidak bertentangan hukum, namun justru pesan tersebut dapat membangkitkan semangat positif bagi semua orang. Semua orang sudah mengerti bahwa kehadiran teknologi informasi dan media sosial bukan tempat melampiaskan kemarahan, membully, menghakimi, mencaci maki, dan memfitnah orang lain. Itu sebabnya Paulus berpesan kepada jemaat Kolose “... buanglah semua itu: kemarahan, kemurkaan, kebencian, fitnah, dan perkataan kotor dari bibirmu" (Kol. 3:8). Dengan nada yang sama diingatkan dan dinasihati oleh Surat Yakobus "Saudara-saudara, janganlah kamu saling memfitnah! Barangsiapa memfitnah saudarnya atau menghakiminya, ia mencela hukum dan menghakiminya; dan jika engkau menghakimi hukum maka engkau bukanlah penurut hukum, tetapi hakimnya" (Yak. 4:11).

Dengan melihat hal ini, maka peran Pendidikan Agama Kristen sangat penting untuk diimplementasikan melawan segala bentuk tindakan-tindakan yang meresahkan

${ }^{10}$ Christiany Juditha, "Interaksi Komunikasi Hoax Di Media Sosial Serta Antisipasinya Hoax Communication Interactivity in Social Media and Anticipation," Jurnal Pekommas 3, no. 1 (1925): 31-44.

${ }^{11}$ Ihsan Ali Fauzi et al., Buku Panduan Melawan Hasutan Kebencian, ed. Ihsan Ali-Fauzi, Pusat Studi Agama Dan Demokrasi, Yayasan Paramadina Masyarakat Anti Fitnah Indonesia (Jakarta Selatan: Pusat Studi Agama dan Demokrasi, Yayasan Paramadina, 2019).

${ }^{12}$ Talizaro Tafonao, "Peran Guru Agama Kristen Dalam Membangun Karakter Siswa Di Era Digital," Journal BIJAK Basileia Indonesian Journal of Kadesi 2, no. 1 (2018): 1-37. 
masyarakat, baik melalui media digital maupun media lain. Peran Pendidikan Agama Kristen mengambil bagian dalam mendidik masyarakat, seperti keluarga, sekolah, warga jemaat dan masyarakat luas ${ }^{13}$ sangat dibutuhkan. Sehingga peranan Pendidikan Agama Kristen di tengah masyarakat dapat dirasakan dampaknya.

\section{Metode Penelitian}

Agar tulisan ini dapat dipahami, maka penulis menggunakan metode penelitian naratif. Penelitian naratif adalah studi tentang kehidupan individu seperti yang diceritakan melalui kisah-kisah pengalaman seseorang, termasuk diskusi tentang makna pengalamanpengalaman individu tersebut. Intinya dari metode ini adalah kemampuannya untuk memahami identitas dan pandangan dunia seseorang dengan mengacu pada cerita-cerita (narasi) yang ia dengarkan ataupun tuturkan di dalam aktivitas sehari-hari. ${ }^{14}$ Dengan demikian, penelitian naratif adalah laporan bersifat narasi yang menceritakan urutan peristiwa secara terperinci. Dalam desain penelitian naratif, peneliti menggambarkan kehidupan individu serta mengumpulkan cerita tentang kehidupan orang-orang atau persolan-persoalan yang sedang hangat dibicarakan dengan menarasikan pengalaman secara individu dalam tulisan. ${ }^{15}$

Berkaitan dengan penjelasan itu maka tulisan ini menceritakan ulang kejadian atau peristiwa-peristiwa yang sudah terjadi dan kemudian penulis menarasikannya dalam sebuah tulisan sebagai karya ilmiah yang dapat dimanfaatkan sebagai rujukan bagi para peneliti berikutnya. Dengan tujuan untuk mendorong masyarakat memiliki kesadaran penuh dalam menggunakan media sosial sebagai sarana berkomunikasi kepada orang lain.

\section{Hasil dan Pembahasan}

\section{Dasar Pemikiran Tentang Pendidikan Agama Kristen}

Dengan memperhatikan penjelasan sebelumnya bahwa kehadiran teknologi di ruang publik menjadi tantangan tersendiri bagi pendidikan khususnya Pendidikan Agama Kristen. Namun tidak berarti Pendidikan Agama Kristen mengklusifkan diri terhadap gejala-gejala yang terjadi di media sosial. Dengan adanya problematika seperti ini maka Pendidikan Agama Kristen harus berani tampil dan menyatakan diri untuk memerangi berita hoaks yang sudah tersebar di media sosial melalui pengajaran Pendidikan Agama Kristen (Mat. 28:19-20), untuk itu Pendidikan Agama Kristen harus mampu menguasi teknologi sebagai bukti keterbukaan terhadap kemajuan yang ada. Tidak ada yang salah dalam mempelajari teknologi. Tetapi Paulus berpesan kepada jemaat di Korintus bahwa "Segala sesuatu halal bagiku, tetapi bukan semuanya berguna. Segala sesuatu halal bagiku, tetapi aku tidak akan membiarkan diriku diperhamba oleh sesuatu apapun" (Kor. 6:12). Artinya bahwa ilmu pengetahuan dan teknologi dapat digunakan oleh siapapun asalkan hal itu tidak berlawanan dengan kebenaran dari Alkitab. Dengan kata lain bahwa Pendidikan Agama Kristen memiliki ruang dalam memainkan perannya untuk memerangi berbagai isu di media sosial dengan membangun spiritualitas masyarakat melalui media teknologi.

Selanjutnya perlu diketahui bahwa Pendidikan Agama mulai ketika agama sendiri muncul dalam hidup manusia. Pendidikan Agama Kristen berpangkal kepada persekutuan umat Tuhan di dalam Perjanjian Lama. ${ }^{16}$ Pendidikan Agama Kristen dimulai dengan

${ }^{13}$ Talizaro Tafonao, "Peran Pendidikan Agama Kristen Dalam Keluarga Terhadap Perilaku Anak," Edudikara: Jurnal Pendidikan dan Pembelajaran 3, no. 2 (2018).

${ }^{14}$ Rizal Mawardi, "Penelitian Kualitatif Pendekatan Naratif."

${ }^{15}$ F.M Clandinin, D.J. \& Conelly, Narrative Inquiry Experience and Story in Qualitative Research (San Fransisco: Jossey-Bass Publishers, 2000).

${ }^{16}$ Homrighausen and Enklaar, Pendidikan Agama Kristen (Jakarta: BPK Gunung Mulia, 2008), 1. 
terpanggilnya Abraham menjadi nenek moyang umat pilihan Allah. Namun perlu diketahui bahwa dasar pendidikan dalam Perjanjian Lama adalah bersumber pada firman Tuhan yang dikomunikasikan langsung kepada pengajar, ${ }^{17}$ yakni Nabi, ahli Taurat dan orang tua. Karena pada dasarnya Pendidikan Agama Kristen memiliki peran penting yakni mendidik dan mengajar berdasarkan firman Tuhan, tetapi pengajaran tersebut harus disesuaikan dengan kebutuhan manusia supaya memahami dan menghayati nilai-nilai yang terkandung di dalamnya serta dapat mengaplikasikannya lewat kehidupan sehari-hari dengan cara berkomunikasi yang baik kepada orang lain, baik secara langsung maupun tidak langsung (media sosial).18 Sama hal dengan Perjanjian Baru dimana semua kitab yang tertulis memiliki tujuan untuk mengajar umat Kristen tentang Allah dalam Yesus Kristus dan pengaruhnya bagi manusia. Sehingga dapat dikatakan bahwa Pendidikan Agama Kristen didasarkan pada firman Tuhan (Alkitab) sebagai sumber utama. Tetapi pendidikan agama dalam Perjanjian Baru mengalami revolusi besar dengan munculnya pengajaran Kristus. Yesus adalah Guru Agung yang memiliki pengaruh besar sehingga banyak orang berbondong-bondong mengikuti kemana Dia pergi. ${ }^{19}$ Oleh karena itu hendaknya Pendidikan Agama Kristen memainkan perannya dalam mengajarkan tentang kebenaran tersebut. ${ }^{20}$ Pendidikan Agama Kristen tidak hanya dilakukan dalam bentuk pendidikan formal seperti di sekolah, tetapi dapat dilakukan lewat kehidupan sehari-hari.

Berdasarkan pemikirkan tersebut maka para pengajar Pendidikan Agama Kristen diharapkan menyadari tugas panggilannya untuk mengabdi kepada gereja, masyarakat, bangsa dan Negara. Jika dihitung dari 3 Januari 1946 sampai tahun 2019, kualitas pendidikan Kristen masih rendah bila dibandingkankan dengan institusi pendidikan agama Islam. ${ }^{21}$ Sehingga tugas utama seorang guru adalah mengajarkan hal-hal yang benar berdasarkan ajaran Alkitab. Guru pendidikan agama kristen di Indonesia harus berjiwa Pancasilais dan setia pada UUD 1945 serta berpedoman pada otoritas Alkitab. Pernyataan tersebut disetujui oleh Andar Gultom mengatakan bahwa salah satu panggilan seorang pendidik Pendidikan Agama Kristen yakni berbakti untuk membimbing peserta didik menjadi manusia Indonesia seutuhnya yang taat dan takut kepada Tuhan dan berjiwa Pancasilais. ${ }^{22}$ Atas dasar pemikiran tersebut maka Pendidikan Agama Kristen harus menjadikan Alkitab sebagai dasar utama dalam mengaplikasikan ilmunya dalam menghadapi berbagai gejala yang ada termasuk di media sosial. Karena pada dasarnya Pendidikan Agama Kristen tidak hanya berlaku pada lembaga Pendidikan Kristen tetapi kepada seluruh pendidikan.

\section{Upaya-Upaya yang Dilakukan Dalam Memerangi Berita Hoaks di Media Sosial}

Di bagian latar belakang, penulis telah menjelaskan bahwa salah satu persoalan yang meresahkan publik hari-hari ini adalah berita hoaks dan berita hoaks akan menjadi ancaman bahkan sumber pemecah belah antara masyarakat satu dengan masyarakat yang lain. Vibriza Juliswara berpendapat bahwa kegaduhan yang terjadi media sosial akan merambat

${ }^{17}$ Harianto GP, Pendidikan Agama Kristen Dalam Alkitab E Dunia Pendidikan Masa Kini (Yogyakarta: Andi Offset, 2016), 33.

${ }^{18}$ Ester Rela Intarti, "Peran Guru Pendidikan Agama Kristen Sebagai Motivator."

${ }^{19} \mathrm{GP}$, Pendidikan Agama Kristen Dalam Alkitab \& Dunia Pendidikan Masa Kini., hlm. 37

20Santy Sahartian, Pemahaman Guru Pendidikan Agama Kristen Tentang II Timotius 3:10 Terhadap Peningkatan Kecerdasan Spiritual Anak Didik, JURNAL FIDEI, vol. 1, 2018.

${ }^{21}$ Elia Tambunan, "GERAKAN TRANSNASIONAL KRISTEN: WAJAH EKONOMI-POLITIK AGAMA DAN PENDIDIKAN DI INDONESIA" 1, no. 1 (2019): 1-17, https://ojsjireh.org/index.php/jireh/article/view/4/10.

${ }^{22}$ Andar Gultom, Profesionalisme: Standar Kompetensi Dan Pengembangan Profesi Guru PAK (Bandung: Bina Media Informasi, 2007), 28-37). 
ke dunia nyata jika hal itu tidak segera diatasi. Karena perbincangan yang terjadi di media sosial berpotensi menciptakan opini yang salah kepada lawan pembicara dan masyarakat. ${ }^{23}$ Anggapan ini terbukti sebagaimana yang dilansir oleh koran Akurat.com pada tanggal 17 Mei 2019 di Dusun Sari Agung, Kampung Buyut Udik dan Dusun 3 Sungai Raya, Kecamatan Gunung Subuh, Propinsi Lampung. Awalnya terjadinya bentrok antara warga dengan warga hanya gara-gara salah paham, karena informasi hoaks yang disebarkan oleh salah satu warga sehingga memicu pertengkaran.

Penyebaran informasi yang begitu mudah dan cepat perlu disikapi dengan baik. Tentu saja dalam menyikapinya seseorang perlu memiliki standar. Bukan standar dunia tetapi standar dari Firman Tuhan. Karena itu karakater seseoranglah yang menjadi kunci utama. Pemazmur mengingatkan "Ajarlah kami menghitung hari-hari kami sedemikian, hingga kami beroleh hati yang bijaksana" (Mzm. 90:12). Pada saat seseorang menjadi cukup dewasa untuk menyadari betapa singkatnya hidup ini, maka ia mulai sadar betapa berharganya seandainya ia telah belajar lebih awal untuk menjadi bijaksana dalam kehidupan. Paulus menasihati, "Karena itu, perhatikanlah dengan saksama, bagaimana kamu hidup, janganlah seperti orang bebal, tetapi seperti orang arif, dan pergunakanlah waktu yang ada, karena hari-hari ini adalah jahat. Sebab itu janganlah kamu bodoh, tetapi usahakanlah supaya kamu mengerti kehendak Tuhan" (Ef. 5:15-17). Dengan ayat ini dapat dipahami, jika seseorang berusaha sungguh-sungguh untuk memiliki hikmat dari Allah, maka akan lebih mampu meningkatkan kualitas dirinya serta mengembangkan karakter dan nilai-nilai yang sudah ditanamkan oleh Allah sejak hidup ini dipulihkan (lahir baru). Itulah sebabnya Tuhan Yesus berpesan kepada murid-murid-Nya jadi garam dan terang bagi semua orang. Dengan demikian maka orang lain akan melihat dan memuliakan Allah (Mat. 5:13-16). Dengan kata lain bahwa karakter sangat berpengaruh terhadap segala aspek kehidupan seseorang, karena melalui hidupnya dapat menjadi saksi Kristus yang paling efektif. ${ }^{24}$

Berdasarkan penjelasan di atas, maka Peran Pendidikan Agama Kristen dalam upaya memerangi berita hoaks di media sosial dapat digambarkan sebagai berikut: pertama, mengajarkan untuk jangan berbohong. Di dalam Kitab Keluaran mengatakan “Janganlah engkau menyebarkan kabar bohong; janganlah engkau membantu orang yang bersalah dengan menjadi saksi yang tidak benar (Kel. 23:1). Ini salah satu perintah Allah kepada umat-Nya, yakni jangan berbohong. Berbohong adalah salah satu kesalahan yang sering dilakukan oleh setiap orang tanpa menyadarinya sehingga tidak sedikit orang menganggap sepele, bahkan ada yang berpendapat bahwa berbohong adalah hal biasa. Pada hal berbohong salah satu tindakan yang sengaja menyembunyikan sebagian besar dari kebenaran. ${ }^{25}$ Tuhan tidak menghendaki anak-anaknya berbohong, karena berbohong memiliki dampak negatif terhadap diri sendiri dan orang lain. Misalnya kasus Ratna Sarumpaet pada tahun 2018, Polisi menetapkan Sarumpaet sebagai tersangka karena telah menyebarkan berita bohong (hoaks) tentang penganiayaan terhadap dirinya. Pada hal kejadian ini tidak benar ketika para penegak hukum menelusuri kebenarannya, sehingga dirinya dijerat dengan Pasal 14 dan 15 dan Undang-undang No 1 tahun 1946 tentang

${ }^{23}$ Vibriza Juliswara, "Mengembangkan Model Literasi Media Yang Berkebhinnekaan Dalam Menganalisis Informasi Berita Palsu (Hoax) Di Media Sosial," Jurnal Pemikiran Sosiologi 4, no. 2 (2017): 142.

${ }^{24}$ Handreas Hartono, "Membentuk Karakter Kristen Pada Anak Keluarga Kristen," Kurios 2, no. 1 (2018): 62.

25Timotius Fu, "Bohong Putih Ditinjau Dari Perspektif Etika Kristen Dan Pengajaran Alkitab," Veritas: Jurnal Teologi dan Pelayanan 8, no. 1 (2007): 111-127. 
peraturan hukum pidana serta pasal 28 yang berkaitan dengan pasal 45 Undang-Undang informasi dan Transaksi Elektronik (UU ITE).

Berdasarkan kasus tersebut di atas dapat artikan bahwa kini media sosial tidak lagi menjadi alat utama dalam berkomunikasi, justru media sosial telah beralih fungsi sebagai tempat penebar kebohongan atau hoaks. Kasus Ratna di atas menjadi salah satu contoh ril dimana para pembuat kebohongan tersebut merancangnya dalam bahasa lisan dan tulisan yang dikemas untuk meyakinkan masyarakat bahwa kejadian tersebut benar-benar terjadi. Jika hal ini dibiarkan terus-menerus maka yang terjadi adalah berdampak pada suatu kehancuran karakter bangsa. Oleh karena itu sebagai umat Tuhan harus memiliki karakter Allah dalam memfilterkan hidupnya untuk menghadapi berbagai pengaruh dunia yang menjerumuskan pada hal-hal negatif. Dengan adanya karakter Allah dalam diri seseorang maka tidak mudah kompromi dengan dosa tetapi yang terjadi adalah mengajarkan tentang kasih, kemurahan hati, kesetiaan, dan kesabaran. ${ }^{26}$ Dengan demikian, seseorang yang memiliki karakter seperti Allah tidak akan terpengaruh serta tidak menjadi pelaku dalam penyebaran berita hoks di berbagai media sosial bahkan dapat menyikapinya dengan bijaksana atas segala sesuatu yang terjadi.

Kedua, mengajarkan untuk jujur. Kejujuran adalah salah satu perilaku yang harus dimiliki oleh semua orang termasuk orang yang percaya kepada Tuhan Yesus. Dan kejujuran ini perlu diajarkan sejak dini kepada setiap manusia supaya dalam berintraksi kepada sesama tidak menimbulkan hal-hal negatif. Sebab kejujuran didasarkan pada upaya menjadikan dirinya sebagai orang dapat dipercaya dalam memberi informasi melalui perkataan dan media. Tidak semua orang memiliki hati yang jujur dalam memberi segala informasi kepada publik disebabkan karena informasi yang dibagikan di media sosial seringkali orang lupa melakukan verifikasi asal usul dari berita tersebut sehingga tidak terkontrol dan menjadi masalah besar di berbagai media.. ${ }^{27}$ Oleh sebab itu perlu edukasi masyarakat, agar masyarakat memiliki hati yang jujur dalam menyampaikan segala informasi kepada publik. Dalam Kitab Amsal mengingatkan bahwa "Orang yang jujur dipimpin oleh ketulusannya, tetapi pengkhianat dirusak oleh kecurangannya" (Ams. 11:3).

Dengan ayat ini dapat diduga bahwa tidak semua orang memiliki hati yang jujur dan tulus dalam menyampaikan suatu berita. Hal ini dapat dilihat dalam penjelasan Rieka Mustika bahwa ada banyak orang menyebarkan informasi yang dapat dimanfaatkan oleh setiap orang, tetapi di sisi lain tidak sedikit orang yang tidak bertanggung jawab dalam menyebarkan berita hoaks yang sumbernya tidak akurat, 28 demi kepentingan kelompok, politik, agama bahkan mengambil keuntungan demi memperkaya dirinya sendiri. Selain itu menurut hemat penulis bahwa ada faktor lain sehingga hal ini sering terjadi. Salah satu faktornya adalah adanya kebebasan dalam menggunakan media sosial sehingga hal ini menjadi celah untuk melakukan suatu kejahatan yang dapat merugikan orang lain. Dan anehnya masyarakat tidak sadar akan dampak terhadap ketidakjujuran tersebut. Seperti yang dialami oleh salah satu ibu rumah tangga di Surabaya berisinial NF, dirinya berurusan dengan Polisi. Menurut penjelasan Kombes Pol Trunoyudo Wisnu Andiko Kabid Humas Polda Jatim mengatakan bahwa tersangka ditangkap pada tanggal 8 Meret 2020, karena NF menyebarkan berita hoaks Covid-19 atau memposting informasi di media sosial Facebook bahwa ada pasien suspect virus corona yang tengah dirawat di RSUD Dr Soetomo Surabaya.

${ }^{26}$ Sid Buzzell Boa Kenneth and Bill Perkins, Handbook To Leadership (Jakarta: Yayasan Komunikasi Bina Kasih, 2013).,hlm. 8

${ }^{27}$ Gumilar, Adiprasetio, and Maharani, "Literasi Media: Cerdas Menggunakan Media Sosial Dalam Menanggulangi Berita Palsu (Hoax) Oleh Siswa Sma."

${ }^{28}$ Rieka Mustika, "Etika Berkomunikasi Di Media Online Dalam Menangkal Hoax," Jurnal Diakom 1, no. 2 (2018): 43-50. 
Setelah diselidiki ternyata pasien yang dimaksud oleh tersangka sedang mendapatkan perawatan karena sakit paru-paru. Akibat dari ketidakjujuran dalam memberi informasi kepada publik, masyarakat menjadi resah terhadap postingan yang telah menyebar luas di media sosial.

Oleh karena itu dengan kejadian-kejadian seperti ini menjadi pembelajaran bagi semua orang termasuk orang kristen. Gereja perlu berupaya keras agar Pendidikan Agama Kristen dapat tersampaikan kepada jemaat, agar jemaat memiliki pengetahuan dalam memanfaatkan segala media yang ada di era digital sehingga bisa memilah berita mana yang perlu dikonsumsi dan berita mana yang tidak perlu dibagikan kepada orang lain. Kecerdasan ini hanya dibangun ketika memiliki hubungan yang baik dengan Tuhan.

Ketiga, menjadi bagian dalam melawan berita hoaks. Salah satu peran Pendidikan Agama Kristen adalah mengajarkan bagaimana cara melawan berita hoks yang sedang tersebar di media sosial. Bagian ini, masyarakat dan jemaat harus dilibatkan dan diajarkan untuk menjadi garda terdepan untuk memberantas berbagai kebohongan tersebut. Dengan cara seperti ini telah membantu pemerintah untuk memerangi berbagai isu-isu yang sedang ada di dalam masyarakat. Jika masyarakat tidak mengambil bagian dalam melawan maka sasarannya adalah anak-anak sendiri dan pemuda gereja. Harus disadari bahwa generasi muda terutama pemuda-pemudi sangat rentan dengan dampak hoaks. Sebab generasi muda merupakan paling banyak bersentuhan dengan media sosial sehingga secara tidak langsung generasi muda akan mengalami dampak dari berita hoaks tersebut. Ada beberapa alasan lain mengapa pemuda-pemudi menjadi sasaran dari hoaks, yakni (1) tidak memiliki pengetahuan yang cukup dalam memilah setiap berita yang ada. (2) mudah percaya terhadap berita tanpa melakukan verifikasi kebenarannya. (3) mudah terpancing dengan hal-hal negatif yang berkaitan dengan harga dirinya, kelompok, bahasa, suku, agama, dan ras.

Dengan melihat penjelasan di atas, maka salah satu cara menangani maraknya berita hoaks di media sosial adalah harus dimulai dari masyarakat sendiri dengan cara mempelajari, memahami, dan mengetahui ilmu komunikasi dengan benar. Dengan cara seperti ini, maka dapat memahami pesan komunikasi yang perlu disebarluaskan dan mana yang tidak perlu disebarluaskan. ${ }^{29}$ Oleh karena itu, masyarakat dan anak-anak muda perlu diperlengkapi secara literasi dalam menghadapi penyebaran berita hoaks di media sosial. Seperti yang dilakukan oleh Kementerian Komunikasi dan Informatika pada tanggal 3 November 2017 di Lampung tentang Sosialisasi Literasi Cerdas Bermedia Sosial. Tujuan kegiatan ini adalah mengajak masyarakat agar lebih cerdas dalam menggunakan media sosial serta mengedukasi masyarakat untuk meningkatkan kecerdasan dalam literasi digital. Dengan kegiatan-kegiatan seperti ini salah satu cara bagi masyarakat dalam menyikapi berbagai persoalan yang terjadi di media sosial. Tidak hanya cerdas tetapi menjadi promotor dalam menangkal tersebar luasnya hoaks diberbagai media. Hal yang sama ditambahkan oleh Mac Aditiawarman. Ia mengatakan bahwa dalam menekan peredaran hoaks di media sosial maka masyarakat mengambil bagian dalam memberi klarifikasi terhadap hoaks, agar tidak memicu persoalan baru dan serta memiliki sikap anti fitnah..$^{30}$ Selain itu ada beberapa hal lain yang harus dilakukan oleh masyarakat sebagai bagian dalam melawan berita hoaks antara lain: membudayakan etika berinternet, mengupgrade diri terhadap hal-hal baru dan memfilterkan setiap informasi dengan bijak. Itu sebabnya Paulus berpesan kepada jemaat di Filipi mengatakan "Jadi akhirnya, saudara-saudara, semua yang benar, semua yang mulia,

${ }^{29}$ Mukti Ali, Melawan Hoax Di Media Sosial Dan Media Massa: Antara Komunikasi, Budaya Dan Hoax (Yogyakarta: Trusmedia Publishing, 2017), 138.

${ }^{30}$ Mac Aditiawarman, Hoax Dan Hate Speech Di Dunia Maya (Padang: Lembaga Kajian Aset Budaya Indonesia Tonggak Tuo, 2019), 178. 
semua yang adil, semua yang suci, semua yang manis, semua yang sedap didengar, semua yang disebut kebajikan dan patut dipuji, pikirkanlah semuanya itu" (Flp. 4:8). Selain bijaksana memfilter setiap informasi, faktor ibadah menjadi bagian penting dalam membangun diri agar dapat menjadi saksi bagi dunia. Yonatan Sumarto menegaskan, adanya ibadah telah membawa kehendak Allah dialami oleh orang percaya, dan orang percaya harus melaksanakan misi Allah bagi dunia. ${ }^{31}$ Umat Allah telah menjadi objek, sekaligus subjek dalam pelaksanaan misi Allah bagi gereja dan dunia.

\section{Langkah-Langkah Praktis Dalam Memerang Berita Hoaks di Media Sosial}

Selain kajian dan poin-poin di atas, maka ada beberapa langkah-langkah praktis dalam memerangi berita hoaks di media sosial yang terus berkembang saat ini. Selain berpegang pada kebenaran Firman Tuhan sebagai landasan tentunya masyarakat juga perlu melakukan antisipasi antara lain: (1) Pastikan terlebih dahulu pesan yang diterima dengan memeriksa situs yang terpercaya. Contoh: hoax.id. (2) Jika berita itu benar pastikanlah apakah berita itu perlu untuk diketahui orang lain atau tidak. (3) Jika tidak benar maka tidak perlu disebarluaskan kembali. Alasan ini dapat diterima, karena masyarakat tingkat literasinya masih sangat rendah dan akibatnya masyarakat mudah menerima informasi tanpa melakukan pengecekan.32 Selanjutnya, langkah-langkah yang dapat dilakukan dalam mengatisipasi berita hoaks sudah dapat dilihat dalam surat kabar online. Selain itu dalam percakapan grup diskusi anti-hoaks di media sosial terhadap sejumlah fanpage, misalnya Forum Anti Fitnah, Hasut, dan Hoaks (FAFHH), Fanpage \& Group Indonesia Hoaks Buster, Fanpage Indonesia Hoaxes, dan Grup Sekoci. Melalui grup-grup diskusi ini, masyarakat dapat ikut bertanya, apakah suatu informasi merupakan hoaks atau bukan, sekaligus melihat klarifikasi yang sudah diberikan oleh orang lain.

Beberapa hal yang dapat dilakukan menurut media online dalam mengatisipasi berita hoaks yaitu: ${ }^{33}$ pertama, jangan cuma judulnya. Banyak orang sebenarnya tidak membaca kontennya. Oleh karena itu, untuk mencegah diri dari penyebaran hoaks, hilangkan kebiasaan membagikan konten tanpa membaca isinya secara menyeluruh. Kedua, orang sering tidak mempertimbangkan legitimasi sumber berita. Situs berita hoaks bisa muncul tiap saat, tetapi sebenarnya bisa menghindari jebakannya dengan bersikap lebih hati-hati melihat sebuah situs yang terpercaya. Ketiga, orang-orang cenderung mudah terkena bias informasi.

Keempat, orang cenderung mudah terkena hoaks ketika menyukai konten yang memperkuat ideologi diri atau kelompoknya. Kelima, orang mengukur legitimasi konten dari berita terkait sebuah berita. Keenam, orang mengukur legitimasi konten dari berita terkait. Sebuah berita belum tentu hoaks hanya karena melihat konten di media sosial, maka seseorang buru-buru menyimpulkan setelah itu dibagikan kepada orang lain. Jangan salah, hoaks ini bisa bersumber dari berita terpercaya, tetapi isinya sudah diplintir. Ketujuh, makin sering orang melihat sebuah konten, makin mudah seseorang mempercayainya, hal ini dipengaruhi karena orang banyak melihat sehingga akhirnya dishere kepada orang lain, tanpa mengecek kebenaran yang sesungguhnya.

${ }^{31}$ Yonatan Sumarto, “Tinjauan Teologis Tentang Ibadah Bagi Pelaksanaan Misi Allah Theological Review of Worship For the Implementation of God 's Mission," Jaffray 17, no. 1 (2019): 57-72.

32Luthfi Maulana, "Kitab Suci Dan Hoax: Pandangan Alquran Dalam Menyikapi Berita Bohong," Wawasan: Jurnal Ilmiah Agama dan Sosial Budaya 2, no. 2 (2017): 209-222.

${ }^{33}$ Latief, "Cara Cerdas Mencegah Penyebaran Hoax Di Media," Kompas.Com. 


\section{Kesimpulan}

Berdasarkan kajian dan penjelasan tentang perkembangan teknologi informasi di atas maka dalam bagian ini penulis hendak mengatakan bahwa kehadiran teknologi informasi saat ini telah mengubah banyak hal termasuk dalam hal berkomunikasi melalui media sosial. Namun dalam perkembangannnya media sosial mengalami pergeseran. Hal ini nampak dalam kajian dan pengamatan secara empiris bahwa begitu masifnya persebaran hoaks di media sosial sehingga memberi dampak negatif yang sangat besar kepada masyarakat yakni lahirnya opini negatif dan ketidakharmonisan dalam masyarakat. Kritiknya adalah Pendidikan Agama Kristen selama ini masih belum memainkan fungsi pendidikannya di ruang publik. Buktinya sampai detik ini Pendidikan Agama Kristen masih belum berani menyatakan dirinya dalam menghadapi berbagai problematika yang ada di era digital (media sosial). Itulah sebabnya tulisan ini hadir sebagai upaya untuk mendorong Pendidikan Agama Kristen agar dapat memaminkan perannya dalam menghadapi berbagai gejala-gejala sosial sebagaimana penjelasan dalam tulisan ini. Dengan melihat pemaparan di atas, penulis menemukan wilayah baru di ruang publik sekaitan dengan fenomena hoaks. Media Pembelajaran Pendidikan Agama Kristen menjadi instrumen dalam dunia digital seperti sumbangan baru dalam tulisan ini. Artinya, media pembelajaran Pendidikan Agama Kristen seperti selama ini diajarkan di Prodi Pendidikan Agama Kristen sudah seharusnya diperbaiki bukan lagi bersifat informatif tetapi juga intervensi.

\section{Rujukan}

Aditiawarman, Mac. Hoax Dan Hate Speech Di Dunia Maya. Padang: Lembaga Kajian Aset Budaya Indonesia Tonggak Tuo, 2019.

Ali, Mukti. Melawan Hoax Di Media Sosial Dan Media Massa: Antara Komunikasi, Budaya Dan Hoax. Yogyakarta: Trusmedia Publishing, 2017.

Boa Kenneth, Sid Buzzell, and Bill Perkins. Handbook To Leadership. Jakarta: Yayasan Komunikasi Bina Kasih, 2013.

Cholik, Cecep Abdul. "Pemanfaatan Teknologi Informasi Dan Komunikasi Untuk Meningkatkan Pendidikan Di Indonesia." Syntax Literate $\square$ : Jurnal Ilmiah Indonesia 2, no. 6 (2017): 21-31.

Clandinin, D.J. \& Conelly, F.M. Narrative Inquiry Experience and Story in Qualitative Research. San Fransisco: Jossey-Bass Publishers, 2000.

Fauzi, Ihsan Ali, Irsyad Rafsadia, Ali Nursahid, Santi Indra Astuti, Dyah Ayu Kartika, Siswo Mulyartono, and Muhammad Khairil. Buku Panduan Melawan Hasutan Kebencian. Edited by Ihsan Ali-Fauzi. Pusat Studi Agama Dan Demokrasi, Yayasan Paramadina Masyarakat Anti Fitnah Indonesia. Jakarta Selatan: Pusat Studi Agama dan Demokrasi, Yayasan Paramadina, 2019.

Fu, Timotius. "Bohong Putih Ditinjau Dari Perspektif Etika Kristen Dan Pengajaran Alkitab." Veritas $\square$ : Jurnal Teologi dan Pelayanan 8, no. 1 (2007): 111-127.

GP, Harianto. Pendidikan Agama Kristen Dalam Alkitab \& Dunia Pendidikan Masa Kini. Yogyakarta: Andi Offset, 2016.

Gultom, Andar. Profesionalisme: Standar Kompetensi Dan Pengembangan Profesi Guru PAK. Bandung: Bina Media Informasi, 2007.

Gumilar, Gumgum, Justito Adiprasetio, and Nunik Maharani. "Literasi Media: Cerdas Menggunakan Media Sosial Dalam Menanggulangi Berita Palsu (Hoax) Oleh Siswa Sma." Pengabdian Kepada Masyarakat 1, no. 1 (2017): 35-40.

Hartono, Handreas. "Membentuk Karakter Kristen Pada Anak Keluarga Kristen." Kurios 2, no. 1 (2018): 62.

Homrighausen, and Enklaar. Pendidikan Agama Kristen. Jakarta: BPK Gunung Mulia, 2008. 
Intarti, Ester Rela. "Peran Guru Pendidikan Agama Kristen Sebagai Motivator." Last modified 2016. Accessed January 31, 2020. http:/ / ejournal.uki.ac.id/index.php.

Juditha, Christiany. "Interaksi Komunikasi Hoax Di Media Sosial Serta Antisipasinya Hoax Communication Interactivity in Social Media and Anticipation." Jurnal Pekommas 3, no. 1 (1925): 31-44.

Juliswara, Vibriza. “Mengembangkan Model Literasi Media Yang Berkebhinnekaan Dalam Menganalisis Informasi Berita Palsu (Hoax) Di Media Sosial." Jurnal Pemikiran Sosiologi 4, no. 2 (2017): 142.

Latief. "Cara Cerdas Mencegah Penyebaran Hoax Di Media." Kompas.Com.

Ma'ruf, Irfan. "Polri Amankan 22 Pelaku Penyebar Hoaks Virus Korona Di Indonesia." INews.Id.

Maulana, Luthfi. "Kitab Suci Dan Hoax: Pandangan Alquran Dalam Menyikapi Berita Bohong." Wawasan: Jurnal Ilmiah Agama dan Sosial Budaya 2, no. 2 (2017): 209-222.

Mustika, Rieka. "Etika Berkomunikasi Di Media Online Dalam Menangkal Hoax." Jurnal Diakom 1, no. 2 (2018): 43-50.

Ngafifi, Muhamad. "Kemajuan Teknologi Dan Pola Hidup Manusia Dalam Perspektif Sosial Budaya." Jurnal Pembangunan Pendidikan: Fondasi dan Aplikasi 2, no. 1 (2014): 33-47.

Nurmalasari, and Devi Wulandari. "Pengaruh Penggunaan Gadget Terhadap Tingkat Prestasi Siswa SMPN Satu Atap Pakisjaya Karawang." JURNAL ILMU PENGETAHUAN DAN TEKNOLOGI KOMPUTER 3, no. 2 (2018): 111-118.

Parsaorantua, Pasaribu Humisar, Yuriewati Pasoreh, and Sintje A. Rondonuwu. "Implementasi Teknologi Informasi Dan Komunikasi (Studi Tentang Web EGovernment Di Kominfo Kota Manado)." Acta Diurna VI, no. 3 (2017): 1-14.

Rahadi, Dedi Rianto. "Perilaku Pengguna Dan Informasi Hoax Di Media Sosial." Jurnal Manajemen Dan Kewirausahaan 5, no. 1 (2017): 58-70.

Rizal Mawardi. "Penelitian Kualitatif Pendekatan Naratif."

Sahartian, Santy. Pemahaman Guru Pendidikan Agama Kristen Tentang II Timotius 3:10 Terhadap Peningkatan Kecerdasan Spiritual Anak Didik. JURNAL FIDEI. Vol. 1, 2018. Accessed December 9, 2019. http://www.stt-tawangmangu.ac.id/e-journal/index.php/fidei.

Sherlyanita, Astrid Kurnia, and Nur Aini Rakhmawati. "Pengaruh Dan Pola Aktivitas Penggunaan Internet Serta Media Sosial Pada Siswa SMPN 52 Surabaya." Journal of Information Systems Engineering and Business Intelligence 2, no. 1 (2016): 17.

Sumarto, Yonatan. "Tinjauan Teologis Tentang Ibadah Bagi Pelaksanaan Misi Allah Theological Review of Worship For the Implementation of God ' s Mission." Jaffray 17, no. 1 (2019): 57-72.

Tafonao, Talizaro. “Peran Guru Agama Kristen Dalam Membangun Karakter Siswa Di Era Digital." Journal BIJAK Basileia Indonesian Journal of Kadesi 2, no. 1 (2018): 1-37.

- - - "Peran Pendidikan Agama Kristen Dalam Keluarga Terhadap Perilaku Anak." Edudikara: Jurnal Pendidikan dan Pembelajaran 3, no. 2 (2018).

Tambunan, Elia. "Gerakan Transnasional Kristen: Wajah Ekonomi-Politik Agama Dan Pendidikan Di Indonesia." Jurnal Ilmiah Religiosity Entity Humanity (JIREH) 1, no. 1 (May 2019): 1-17. https://ojs-jireh.org/index.php/jireh/article/view/4. 